Economy

Belova Inna, Ph. D, Associate Professor, Departament of Banking, Korenyeva Oksana, Ph. D, Associate Professor, Departament of Banking, Ukrainian Academy of Banking of the National Bank of Ukraine

\title{
Application requirements of international institutions to organizations of financial monitoring / AML in Ukraine in the struggle against corruption
}

Summary. In this paper the influence of corruption on Ukrainian economy is investigated. Negative effects of corruption are identified. The common trends and consequences of increasing corruption in Ukraine are analyzed.

Keywords : money laundering, corruption, bribery, PEPs (Politically Exposed Persons).

\section{Introduction.}

In all times and in all countries philosophers, famous artists paid much attention to corruption. The English philosopher Thomas Hobbes wrote: «Corruption is the root from which follows at all times and under all temptations contempt for all laws».

The quotation of Alexander Herzen: "If all the laws would be strictly complied and nobody took bribes, the life would be impossible" unfortunately, can't be applied exclusively to Russia. Experts who study the question of corruption in different countries, conclude that corruption sometimes attempt to do something to bypass the law, bribe for accelerating the process of getting services from official is the national feature, including countries in Africa, Latin America and even in Italy. Thus, it doesn't matter what were the force there would be always those who bypass the law, as relations to possible violations of the law are the matter of ethical principles. 
Questions deal with struggle against corruption and bribery were paid much attention in recent years worldwide. These crimes are predictable along with such as: terrorism and its financing, human trafficking, illegal turnover of drugs and others.

FATF has issued several conceptual documents on fighting corruption in the summer of 2011: «Corruption», «Laundering the Proceeds of Corruption». Substantial attention in the last document is given to examples of corruption by Lazarenko (extortion, money laundering, using the accounts in offshore jurisdictions for this purpose, involvement in the kidnapping and murder - this is a list of facts of his crimes).

In the above mentioned documents of FATF main directions of receiving corruption revenues:

"In the grand corruption context, the most prevalent forms of proceeds are those arising from

- 1) bribe-taking or kickbacks;

- 2) extortion;

- $\quad 3)$ self-dealing and conflict of interest;

- 4) embezzlement from the country's treasury by a variety of fraudulent means ".

\section{Problem.}

Unfortunately, Ukraine also has a widespread corruption, although it does not stand aloof from struggling against it. Thus, in 2010-2011 the Law of Ukraine N 3206-VI "On Grounds of Corruption Prevention and Counteraction" was adopted (Date of entry into force: July 1, 2011) [3] and some amendments were done according to other laws and codes. " The National anti-corruption strategy for 2011 2015 years" [2] was elaborated, and in 2010 The National Anti-Corruption Committee was created.

But in spite of such significant positive changes in Ukraine there are still many claims made by Greco (Group of States against Corruption, Directorate General of Human Rights and Legal Affairs, Directorate of Monitoring Council of Europe), as 
defined in the document «Addendum to the Compliance Report on Ukraine », which was issued in Strasbourg, 23-27 May 2011.

Greco expressed concerns about the existence of two parallel systems of corruption offences, i.e. the criminal and the administrative system, which affords opportunities for manipulation, for example, to escape from the justice process.

The document draws attention to the numerous shortcomings of the judicial system in Ukraine.

Mentioned in «Laundering the Proceeds of Corruption» the risks and shortcomings promote the growing role of PEPs (Politically Exposed Persons) in corruption and money laundering.

PEP makes extensive using of banks for cash flow. Example: Pavel Lazarenko and his colleagues for this purpose controlled 2 banks: European Federal Credit Bank ("Eurofed") and Postabank, registered in foreign jurisdictions.

Another example: The U.S. Senate revealed U.S. banks (with branches in the UK) that did not take adequate measures of KYC in the case of the accounts of two Sani Abacha's sons - Nigerian military and statesman.

Corrupt officials have a number of significant advantages over other criminals:

- they can control the state machinery, including those who are obliged to reveal such crimes to affect the appointment of "necessary" people;

- through the funding of political parties they can strengthen control of the government;

- they involve the most qualified professionals in the country to take part in operations;

- they guarantee the diplomatic cover;

- they have a respectable appearance and the corresponding image, deflecting suspicion.

Moreover, corruption is usually associated with the outflow of capital. Current estimates of illegal financial flows has been increased from 1.26 trillion $\$$ to 1.44 trillion \$, which are flowing away from the poorest countries in 2008 . 
From February 1, 2012 The Ministry of Justice should ensure implementation of the Unified State Register of persons who have committed corruption.

The purpose of the registry is providing background check information about individuals who apply for positions, connected with the functions of the state or local government, and to determine the positions of the major corruption risks.

The "Analytical report on corruption risks in the spheres of administrative services and oversight of public administration in Ukraine" [1] gives the results of the study of corruption in the provision of administrative services, lists of the major corruption risks and proposals for their reduction are presented. These, for example, are the following:

- do not include in the State Budget Law provisions on the financing of government from the proceeds of fines they impose;

- to establish by law the most common ways to address the administrative entity for the service using email communications, email, phone orders;

- to avoid duplication of illegal acts syllables in the Code of Administrative Offences, Criminal Code and sectoral legislation;

- other.

Many issues and corruption risks which are listed in the "Analytical report ..." [1] are typical in all countries of the world, but significant corruption is defined only in some of them. This, on our opinion, is due to the peculiarities of the country, that is, its civilization identity.

Samuel Phillips Huntington in his monography «The Clash of Civilizations and Remaking of the World Order» and in the article «The Clash of Civilizations?» described the decisive influence of civilization belonging on the development of the country, on the relations between countries. According to Huntington civilization is the highest cultural education that connects people and provides them with a degree of cultural identity. In this sense, civilization is defined by common objective elements, such as language, history, religion, customs, social institutions, as well as subjective self-identification of people. Huntington distinguishes some civilizations: 
Western, Hispanidad (Latin American), Japanese, Sinic, Hindu, Islamic, Orthodox, African, Buddhist.

For Orthodox Civilization, as for any other, a common language, history, religion and customs are typical features. There is the thesis in the religious traditions of Orthodoxy: repent and receive forgiveness. Therefore, religious and cultural roots of corruption (and many other crimes) are not breaking unavoidability of punishment. Improper severity of punishment or even lack of it conducives to the growth of corruption. Is it so you can find out from the information analysis in the website of the Ministry of Internal Affairs.

The statistical data from the site of the Ministry of Internal Affairs [4] about the number of certain types of crimes and the consequence of criminal case prosecutions are presented in the following tables .

Table 1 - Crimes of organized groups and criminal organizations (material from [4])

\begin{tabular}{|c|c|c|c|}
\hline & 2009 & 2010 \\
\hline \multicolumn{2}{|c|}{ Organized groups and criminal organizations discovered } & 130 & 174 \\
\hline & with corrupt ties & 6 & 13 \\
\hline & with international connections & 15 & 10 \\
\hline & formed on ethnic basis & 2 & 12 \\
\hline \multicolumn{2}{|r|}{$\begin{array}{l}\text { Persons who commit crimes in organized groups and criminal organizations } \\
\text { revealed }\end{array}$} & 486 & 684 \\
\hline \multicolumn{2}{|c|}{ Crimes by organized groups and criminal organizations committed } & 861 & 1247 \\
\hline \multirow{11}{*}{$\begin{array}{l}\text { Certain } \\
\text { types of } \\
\text { crimes }\end{array}$} & Creating a criminal organization & 5 & 10 \\
\hline & Banditry (gangsterism) & 4 & 4 \\
\hline & Murder (and attempted) & 6 & 7 \\
\hline & Brigandage & 28 & 53 \\
\hline & Extortion & 7 & 26 \\
\hline & Hostage-taking & & \\
\hline & $\begin{array}{l}\text { Human trafficking or other illegal agreement on the transfer of } \\
\text { human }\end{array}$ & 32 & \\
\hline & Illicit Weapons & 15 & 9 \\
\hline & $\begin{array}{l}\text { Crimes in narcotic drugs, psychotropic substances or precursors } \\
\text { circulation }\end{array}$ & 209 & 236 \\
\hline & Larceny & 103 & 150 \\
\hline & $\begin{array}{l}\text { Misappropriation, embezzlement or obtaining the property through } \\
\text { abuse of power }\end{array}$ & 91 & 62 \\
\hline
\end{tabular}




\begin{tabular}{|l|l|c|c|}
\hline \multicolumn{2}{|c|}{ Crimes in the sphere of official activity } & 75 & 113 \\
\hline \multirow{2}{*}{$\begin{array}{c}\text { inclu } \\
\text { ding }\end{array}$} & abuse of authority or official duties & 4 & 32 \\
\cline { 2 - 4 } & exceeding one's authority and power & 7 & 6 \\
\cline { 2 - 4 } & bribery & & 15 \\
\hline \multicolumn{2}{|c|}{ Legalization (laundering) of proceeds from crime } & 14 & 17 \\
\hline \multicolumn{2}{|c|}{ Financial fraud } & 1 & 8 \\
\hline
\end{tabular}

Analysis of statistical data from the site of the Ministry of Internal Affairs [4] gives us the number of certain types of crimes and the outcome of criminal cases.

Among the crimes as part of organized groups and criminal organizations corruption offenses have a small share (bribery, abuse of authority, abuse of authority and others, which are the result of getting unlawful benefit.) However, the dynamics of these crimes in recent years is positive, i.e. their number is increasing.

Table 2 shows those regions of Ukraine, where the most common crimes in the sphere of economic activity are committed, and thus, corruption. As for Ukraine's regions so as for certain types of crime in general its number is growing.

Table 2 - Statistical data of crime in sphere of economic activity in some regions of Ukraine

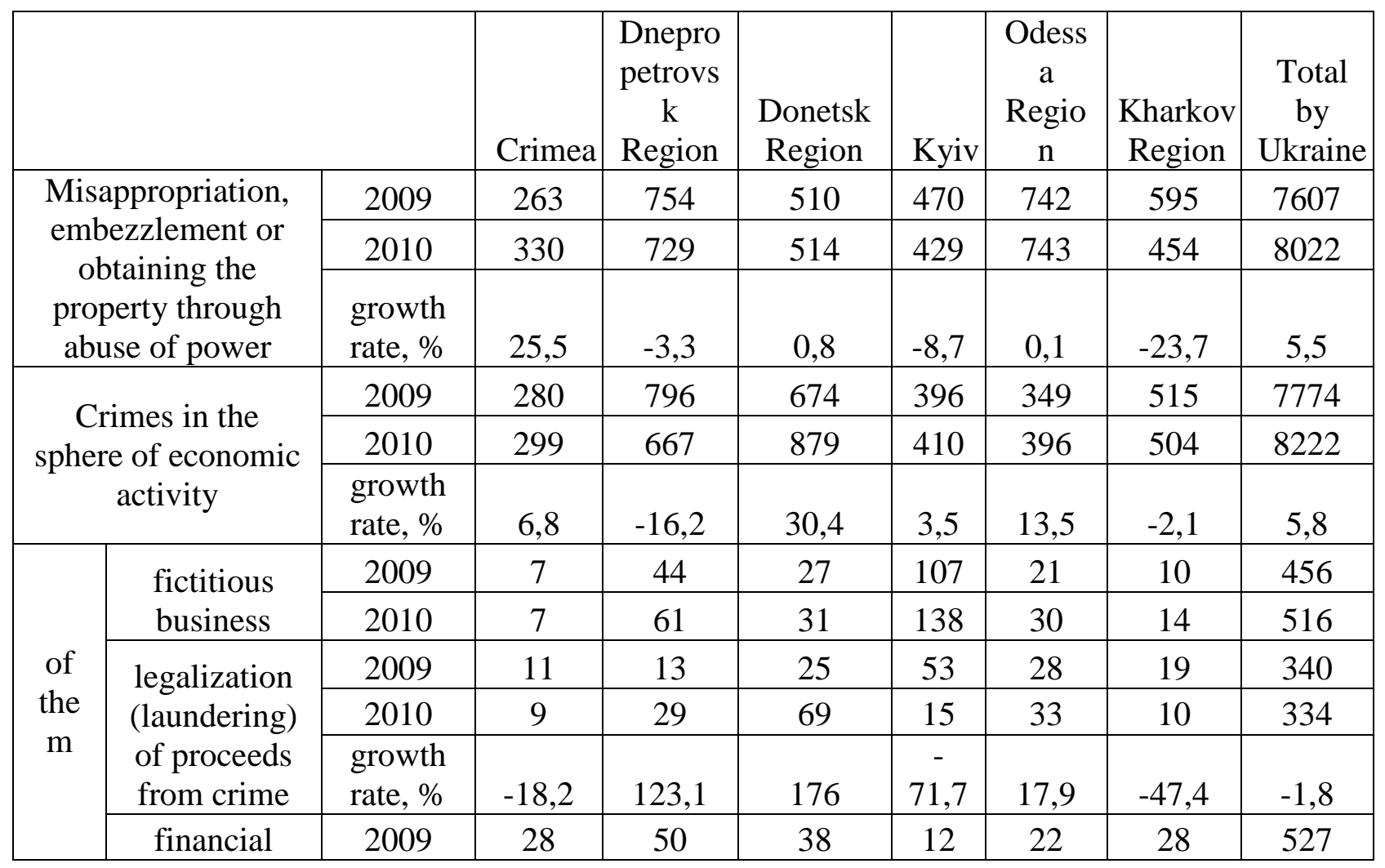


fraud

\begin{tabular}{|c|c|c|c|c|c|c|c|}
2010 & 31 & 75 & 16 & 17 & 15 & 29 & 545 \\
\hline $\begin{array}{l}\text { growth } \\
\text { rate, \% }\end{array}$ & 10,7 & 50 & $-57,9$ & 41,7 & $-31,8$ & 3,6 & 3,4 \\
\hline
\end{tabular}

Bribery has a share in crimes of officials less than $20 \%$. But almost half of passive bribery is registered in 6 regions of Ukraine (from 27). They are: Dnipropetrovsk, Donetsk, Kyiv (city), Luhansk, Odesa, Kharkiv regions.

Table 3 - Crime in the sphere of official activities

\begin{tabular}{|c|c|c|c|c|c|c|c|c|}
\hline \multirow{4}{*}{ Regions } & \multirow{3}{*}{$\begin{array}{c}\text { Crimes in } \\
\text { the sphere of } \\
\text { economic } \\
\text { activity }\end{array}$} & \multicolumn{2}{|c|}{ of which } & \multicolumn{5}{|c|}{ of which } \\
\hline & & \multirow{2}{*}{$\begin{array}{c}\text { abuse of } \\
\text { authority or } \\
\text { official duties }\end{array}$} & \multirow{2}{*}{$\begin{array}{c}\text { exceeding } \\
\text { one's } \\
\text { authority and } \\
\text { power }\end{array}$} & \multirow{2}{*}{\multicolumn{3}{|c|}{ bribery }} & \multicolumn{2}{|c|}{ including } \\
\hline & & & & & & & passive & active \\
\hline & 2010 & 2010 & 2010 & 2009 & 2010 & $\begin{array}{l}\text { growth } \\
\text { rate, } \%\end{array}$ & 2010 & 2010 \\
\hline Crimea & 798 & 182 & 72 & 116 & 128 & 10,3 & 87 & 41 \\
\hline \begin{tabular}{|l} 
Dnepropetro \\
vsk Region \\
\end{tabular} & 2033 & 682 & 76 & 197 & 226 & 14,7 & 212 & 14 \\
\hline \begin{tabular}{|l} 
Donetsk \\
Region \\
\end{tabular} & 1213 & 293 & 48 & 276 & 265 & $-4,0$ & 211 & 54 \\
\hline Kyiv (City) & 874 & 195 & 72 & 182 & 196 & 7,7 & 169 & 27 \\
\hline $\begin{array}{l}\text { Odessa } \\
\text { Region }\end{array}$ & 1396 & 257 & 24 & 353 & 376 & 6,5 & 360 & 16 \\
\hline $\begin{array}{l}\text { Kharkov } \\
\text { Region }\end{array}$ & 600 & 94 & 23 & 137 & 131 & $-4,4$ & 113 & 18 \\
\hline $\begin{array}{l}\text { Total by } \\
\text { Ukraine }\end{array}$ & 17548 & 4461 & 810 & 2707 & 2860 & 5,7 & 2452 & 407 \\
\hline
\end{tabular}

Table 4 - Information about crime in previous years

\begin{tabular}{|c|c|c|c|c|c|c|c|}
\hline \multirow{4}{*}{ Regions } & \multirow{4}{*}{$\begin{array}{c}\text { The } \\
\text { remaining } \\
\text { unsolved } \\
\text { crimes of } \\
\text { previous } \\
\text { years (at } \\
\text { beginning of } \\
\text { year) }\end{array}$} & \multicolumn{6}{|c|}{ of which } \\
\hline & & \multirow{2}{*}{\multicolumn{3}{|c|}{$\begin{array}{l}\text { crimes cases which the } \\
\text { completed investigations }\end{array}$}} & \multirow{3}{*}{ 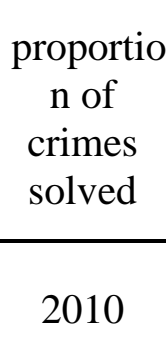 } & \multirow{3}{*}{$\begin{array}{c}\begin{array}{c}\text { removed } \\
\text { from the } \\
\text { register }\end{array} \\
2010\end{array}$} & \multirow{3}{*}{\begin{tabular}{|c} 
in connection with \\
limitation of action
\end{tabular}} \\
\hline & & & & & & & \\
\hline & & 2009 & 2010 & $\begin{array}{l}\text { absolute } \\
\text { growth }\end{array}$ & & & \\
\hline Crimea & 115447 & 886 & 965 & 79 & & 16002 & 15848 \\
\hline $\begin{array}{l}\text { Dnepropetrovsk } \\
\text { iy Region }\end{array}$ & 189056 & 4989 & 4221 & -768 & 2,2 & 18851 & 18532 \\
\hline
\end{tabular}




\begin{tabular}{|l|c|c|c|c|c|c|c|}
\hline $\begin{array}{l}\text { Donetskiy } \\
\text { Region }\end{array}$ & 244596 & 1804 & 2188 & 384 & 0,9 & 10951 & 10555 \\
\hline Kyiv (City) & 185873 & 1394 & 1695 & 301 & 0,9 & 17116 & 16673 \\
\hline Luhansk region & 120794 & 3673 & 3848 & 175 & 3,2 & 15110 & 14688 \\
\hline Odessa Region & 99268 & 1317 & 1331 & 14 & 1,3 & 8685 & 8540 \\
\hline Kharkov Region & 130361 & 2004 & 2112 & 108 & 1,6 & 11890 & 11535 \\
\hline $\begin{array}{l}\text { Total by } \\
\text { Ukraine }\end{array}$ & $\mathbf{1 9 4 4 4 1 6}$ & $\mathbf{2 5 7 7 5}$ & $\mathbf{2 7 1 2 5}$ & $\mathbf{1 3 5 0}$ & $\mathbf{1 , 4}$ & $\mathbf{1 7 2 5 6 9}$ & $\mathbf{1 6 7 6 8 3}$ \\
\hline
\end{tabular}

A large proportion of crimes in previous years are not disclosed (in Ukraine $98.6 \%$ ), due to maturate date are removed from the register. Indicators of crime disclosure significantly depend on the type of crime (see Table 5).

Crimes in the public activity sphere are revealed less often than for example, assault or accidents with fatalities. Crimes in the public activity sphere which are committed with large scale sums are revealed much less than others. The lowest disclosure indicators of such crimes in the activities of public sphere are: a violation of law on the budget system (disclosure $\%$ is less than $50 \%$ ), illegal privatization of the state or public property, illegal activities on privatization issues. It is especially noticeable if we compare with the corresponding crimes indicators of scrap metal disorder (percent of disclosure 95-98\%). For these types of crimes with the lowest disclosure indicators also the highest indicators of removal from the register are typical. Thus, $87 \%$ of crimes in violation the law against the budget system are removed from the register. 
Table 5 - Percentage of deregistration and solve crimes

\begin{tabular}{|c|c|c|c|c|c|c|c|c|c|c|c|c|}
\hline & \multicolumn{3}{|c|}{ Registered crimes } & \multicolumn{3}{|c|}{ Investigated crimes } & \multirow{2}{*}{\begin{tabular}{|c|}
$\begin{array}{c}\text { Discontinued } \\
\text { of the } \\
\text { register }\end{array}$ \\
2010
\end{tabular}} & \multirow{2}{*}{$\begin{array}{l}\text { Revealed } \\
\text { people who } \\
\text { have } \\
\text { committed } \\
\text { crimes }\end{array}$} & \multicolumn{2}{|c|}{$\begin{array}{l}\% \text { investigated } \\
\text { crimes }\end{array}$} & \multirow{2}{*}{$\begin{array}{c}\% \\
\begin{array}{c}\% \text { discontinued } \\
\text { of the register }\end{array} \\
2010\end{array}$} \\
\hline & & 2009 & 2010 & $\begin{array}{l}\text { growth } \\
\text { rate, } \%\end{array}$ & 2009 & 2010 & $\begin{array}{l}\text { growth } \\
\text { rate, } \%\end{array}$ & & & 2009 & 2010 & \\
\hline \multicolumn{2}{|c|}{$\begin{array}{l}\text { Misappropriation, } \\
\text { embezzlement or obtaining the } \\
\text { property through abuse of power }\end{array}$} & 7832 & 8240 & 5,2 & 6521 & 7401 & 13,5 & 1267 & 4680 & 83,3 & 89,8 & 15,4 \\
\hline \multirow{2}{*}{\multicolumn{2}{|c|}{\begin{tabular}{|c|c|}
$\begin{array}{c}\text { of } \\
\text { which }\end{array}$ & $\begin{array}{c}\text { in especially large } \\
\text { amounts }\end{array}$ \\
$\begin{array}{c}\text { Crimes in the sphere of } \\
\text { economic activity }\end{array}$ \\
\end{tabular}}} & 1051 & 1001 & $-4,8$ & 676 & 778 & 15,1 & 379 & 514 & 64,3 & $\begin{array}{r}77 \\
, 7 \\
\end{array}$ & 37,9 \\
\hline & & 8176 & 8601 & 5,2 & 6395 & 6672 & 4,3 & 1112 & 5329 & 78,2 & $\begin{array}{r}77 \\
, 6 \\
\end{array}$ & 12,9 \\
\hline \multirow{8}{*}{$\begin{array}{c}\text { of } \\
\text { which }\end{array}$} & fictitious business & 460 & 521 & 13,3 & 321 & 301 & $-6,2$ & 73 & 241 & 69,8 & $\begin{array}{r}57 \\
, 8\end{array}$ & 14,0 \\
\hline & \begin{tabular}{|l|}
\multicolumn{1}{|c|}{ legalization } \\
(laundering) of proceeds \\
from crime
\end{tabular} & 342 & 336 & $-1,8$ & 314 & 296 & $-5,7$ & 73 & 169 & 91,8 & $\begin{array}{r}88 \\
, 1\end{array}$ & 21,7 \\
\hline & \begin{tabular}{|l|} 
violation of the law on \\
budget system
\end{tabular} & 27 & 39 & 44,4 & 16 & 12 & $-25,0$ & 34 & 12 & 59,3 & \begin{tabular}{r|}
30 \\
8 \\
\end{tabular} & 87,2 \\
\hline & \begin{tabular}{|c|} 
violation of the order \\
for scrap metal operations
\end{tabular} & 1149 & 1764 & 53,5 & 1129 & 1678 & 48,6 & 52 & 1653 & 98,3 & $\begin{array}{r}95 \\
1 \\
\end{array}$ & 2,9 \\
\hline & financial fraud & 531 & 547 & 3,0 & 438 & 480 & 9,6 & 161 & 275 & 82,5 & 87,8 & 29,4 \\
\hline & $\begin{array}{r}\text { illegal privatization of } \\
\text { state and public property }\end{array}$ & 45 & 26 & $-42,2$ & 28 & 19 & $-32,1$ & 13 & 18 & 62,2 & 73,1 & 50,0 \\
\hline & $\begin{array}{l}\text { illegal activities of } \\
\text { privatization papers }\end{array}$ & 23 & 4 & $-82,6$ & 2 & 2 & & 18 & 2 & 8,7 & 50,0 & 450 \\
\hline & $\begin{array}{l}\begin{array}{l}\text { failure by the individual } \\
\text { the required conditions on } \\
\text { privatization }\end{array} \\
\end{array}$ & 44 & 56 & 27,3 & 32 & 50 & 56,3 & 6 & 47 & 72,7 & 89,3 & 10,7 \\
\hline \multicolumn{2}{|c|}{$\begin{array}{l}\text { Crimes in the sphere of } \\
\text { economic activity }\end{array}$} & 17648 & 17980 & 1,9 & 15354 & 16254 & 5,9 & 3894 & 8942 & 87,0 & 90,4 & 21,7 \\
\hline
\end{tabular}




\begin{tabular}{|l|l|r|r|r|r|r|r|r|r|r|r|r|}
\hline \multirow{4}{*}{$\begin{array}{l}\text { of } \\
\text { which }\end{array}$} & $\begin{array}{c}\text { abuse of authority or } \\
\text { official duties }\end{array}$ & $\mathrm{X}$ & 4543 & $\mathrm{X}$ & $\mathrm{X}$ & 3458 & $\mathrm{X}$ & 1605 & 2356 & $\mathrm{X}$ & 76,1 & 35,3 \\
\hline \multirow{2}{*}{\begin{tabular}{l} 
authoeding one's \\
\cline { 2 - 10 }
\end{tabular}} & $\mathrm{X}$ & 827 & $\mathrm{X}$ & $\mathrm{X}$ & 654 & $\mathrm{X}$ & 352 & 576 & $\mathrm{X}$ & 79,1 & 42,6 \\
\hline
\end{tabular}




\section{Results.}

On February, 16 in 2012 new standards «International Standards on Combating Money Laundering and the Financing of Terrorism \& Proliferation» were adopted at the FATF Plenary. These standards in comparison with the previous (2004 edition) undergone some changes, including expanding the list of predicate crimes to include tax crimes, enhanced requirements for AML corruption proceeds, strengthened requirements for use in the financial system-based approach to risk of money laundering and terrorist financing.

Ukraine, like other countries, should carry out the work of bringing national legislation, regulations on combating money, operating in the financial sector.

The following months should be exclusively crammed of events in the financial monitoring system, because you will need to develop a very sophisticated approach considering detection technology transactions subject to obligatory and internal financial monitoring, a new kind of socially dangerous act that precedes the legalization (laundering) proceeds of crime - tax crimes. So banks should take another function - tracking the cash flow of tax criminals.

It aggravates the current system of financial monitoring, as at the state level so as for individual subjects of financial monitoring (i.e., including banks), will require more skilled, more powerful software to detect suspicious transactions, larger expenses.

Companies are faced with corruption, mostly in the business licensing, taxation and customs. OECD stated that corruption is a serious obstacle for doing business in Ukraine.

Officials are usually corrupted. Only availability of effective system for tracking the ratio of their income and expenses can help to identify the proceeds from corrupt activities, which, of course, do not lead to the payment of taxes. In Ukraine there is no obligation for all officials to report about their spending, they only submit a declaration of income.

In addition, the banks will play a great role in the proper identification of clients - national PEPs and qualitative monitoring of their funds origin. 


\section{Conclusion.}

The main conclusions arising from this research are: the only adequate reforming of the anti-corruption is not enough. Legislative changes, judicial reform will solve only part of the problems. The main thing is the ideological work, which with disappearance of Communist Party, is almost absent. There is no concept of educating the youth in a spirit of respect for the work. Media often promote the possibility of easy money; movies talk about luxurious life of officials who violate the law. And the most important - the appetites of criminals (and sometimes officials) are limited to almost nothing. The lack of ideology also promotes it.

\section{References}

1. Аналітичний звіт щодо корупційних ризиків у сферах надання адміністративних послуг та контрольно-наглядової діяльності публічної адміністрації в Україні. Підтримка належного урядування: проект протидії корупції в Україні (UPAC) http://www.minjust.gov.ua/0/21894.

2. National anti-corruption strategy for 2011 - 2015 years, approved by the President of Ukraine from October 21, 2011 N 1001/2011.

3. The Law of Ukraine "On Grounds of Corruption Prevention and Counteraction" April 7, 2011 N 3206-VI.

4. Statistic data from the site of the Ministry of Internal Affairs of Ukraine http://mvs.gov.ua/mvs/control/main/uk/publish/article/717134/.

5. Addendum to the Compliance Report on Ukraine: Greco (Group of States against Corruption, Directorate General of Human Rights and Legal Affairs,

Directorate of Monitoring Council of Europe), Strasbourg, 23-27 May 2011. http://www.coe.int/t/dghl/monitoring/greco/documents/2011/Greco(2011)7_Decisi onsGR51_EN.pdf.

Belova, I. V. Application requirements of international institutions to organizations of financial monitoring /AML in Ukraine in the struggle against corruption [Text] / I. V. Belova, O. G. Korenyeva,- Przemysl : Nauka i Studia. - 2012. - NR 5(50). P. 47-55. 